\title{
7 The 'housebroken' far-right parties and the showdown in Danish migration and integration policies
}

\author{
Shahamak Rezaei and Marco Goli
}

\section{Introduction}

Therefore, I say to the Danish People's Party (DP): No matter how many efforts you make - in my eyes - housebroken, you never will become.

(Prime Minister Poul Nyrup Rasmussen, Opening debate in the Danish

Parliament, 7 October 1999)

Migration and integration policies in Denmark have been linked not only with one another but also, increasingly, with many other policy areas. The conflict on whether migration management and integration policies have been a success seems to be settled. These policies are widely considered to be failures as far as migrants of and descendants from non-Western countries - notably Muslim immigrants are concerned. Nevertheless, the debate continues between competing political and societal actors, all seeking support from 'objective' observations - i.e. statistical 'evidence'. On the other hand, there is no doubt that the dominant interpretation (of the results of previous migration management and integration policies) has influenced a wide range of policy areas. This is specifically the case with regard to reforms in the field of labour-market, social and welfare policies and education. These policy areas have undergone tremendous, even fundamental, changes which, in academic and political circles, are usually addressed as the institutionalisation of a dominant 'neoliberal' discourse (Torfing 2003). The two most obvious impacts of the development of migration and integration policies on development in other areas are election outcomes and the move from a universal to a particular welfare state:

- Election outcomes - changes in public opinion have been decisive with regard to who, among the competing political parties and coalitions, has actually succeeded in taking over governmental power. Typically, migration management and integration policy has been one of the very top issues in political debates prior to national elections for decades. On the other hand, the voters' evaluation of the outcomes of the practices and priorities of parties in government within migration management and integration has been decisive on the issue of whether or not to let them continue to run the country. 
- From universal to particular welfare state - the 'objective facts' and subjective attitudes have contributed to pushing fundamental changes through in migration management policies themselves. Paradoxically, these changes quite often had consequences for natives, too, of which reforms in social citizenship (i.e. conditions that are to be met in order to be entitled to and eligible for certain social benefits and rights - reform of the cash aid system being the most discussed and contested) are only one. With Denmark being a universal welfare state par excellence over many years, a number of policy reforms, specifically within the field of welfare policy - i.e. the redistribution of wealth and social rights - have been introduced, with the status and attitudes of migrants from non-Western countries being the implicit and recently quite outspoken legitimation when arguing that the 'sustainability of the universal welfare state' is at stake. This is despite the fact that the principles on which the 'universal' welfare state is built and developed exclude a focus on ethnicity, religious or national background as criteria for inclusion. On the other hand, the proclaimed goals and widely shared premises, when arguing for the necessity of such policy changes, have been a reduction in both the number and the rights of migrants from non-Western countries.

Reforms in labour-market, social and welfare policies are not the only manifest indications of how a (supposed) failure in migration management and integration policies has contributed to societal changes in recent years. Many other areas have been influential, including cultural policies, national-identity discourses, crime management, housing and reforms in the education system etc. It seems that the right-wing parties have managed to bring about answers to what are publicly and increasingly perceived as major challenges to both current and future society. Mainstream parties had not been able to sufficiently address the challenges but, over the last few decades, have been remarkably successful at adopting definitions and solutions to the problem that have been introduced by 'so-called' radicalwing parties.

The aim of this chapter is to provide an understanding of how perspectives on migration and integration which, a few decades ago, were considered to be 'radically right', are a today mainstream policy in Denmark. First, we explain the categories in use in the Danish debate on migration management and integration policy. Second, we elaborate on the historical responses to challenges of immigration and integration. A description of the current results of integration policies follows, where we focus exclusively on non-Western migrants and their descendants, particularly on their records within certain spheres of citizenship. This description will be followed by elaborations on the impact of EU enlargement and the similarities and differences between two periods - the early 1970s, when the first non-Western migrants came to Denmark and this last decade, when labour from Eastern European member-countries of the EU found their way to Denmark. This discussion will be followed by an elaboration on the very recent changes in the Danish policy within migration management and integration. The concluding part will present future perspectives on Danish migration management 
and integration and why the radical right's framing of the challenges and solutions seems to be durable.

\section{Core definitions of categories}

In order to grasp the complexities of integration and migration issues in the Danish context and their overwhelming impact on other areas of policy, it is essential to start by clarifying the definitions of categories established in public debates, academic research and political discourses. According to the 'Integration Barometer' (Udlændinge-og Integrationsministeriet 2019) we usually use the following categories of migrant in Denmark:

- $\quad$ migrants from Western countries, which includes migrants and their descendants from Nordic countries, EU countries, Switzerland, Canada, the USA, Australia and New Zealand,

- migrants from non-Western countries, which includes migrants and their descendants from all other countries.

Apart from this, statistical definitions also shed light on / operationalise the content and connotation of the following core concepts:

- An immigrant is a person born outside Denmark, with neither parent being both a Danish citizen and born in Denmark.

- $\quad A$ descendant is a person who is born in Denmark, with neither parent being both a Danish citizen and born in Denmark.

In Danish migration research, a core distinction has been established between migration policy and integration policy. Migration policy is defined as politics and legislation (and processes and outcomes) that relate to the actual process of immigration to the country. Integration policy, on the other hand, is understood as policy [processes and political outcomes, legislation or lack of the same] that concerns residents from countries other than the Nordic, EU and North America, i.e. persons from the so-called third countries. Here, third countries are defined as countries with social, economic and cultural conditions that are very different from our own, as immigrants from the Nordic countries, the EU and from North America are largely expected to manage themselves (Goli 2002; Bøgelund Nielsen 1984). The purpose of migration policy is to either tighten or liberalise rules on travel and residence permits for foreign nationals, while the purpose of integration policy in Denmark is to do something special for those who have difficulty in the integration process, in order to prevent them from developing into a minority group which could be, at worst, in opposition to society (Bøgelund Nielsen 1984).

\section{The history of immigration and immigration law}

On 1 January 2018, Denmark had 5,781,000 inhabitants, a figure which included approximately 592,000 immigrants and 179,000 descendants of immigrants. 
Among them, about two-thirds were immigrants and descendants from non-Western countries, who thus constituted 8.6 per cent of the population. About 60 per cent of them had their origins in the following nine countries: Turkey (12.6 per cent 60,000 persons), Syria (8.2-40,978 persons), Iraq (6.5-32,494 persons), Lebanon (5.4), Pakistan (5.4), Bosnia and Herzegovina (4.6), Somalia (4.3), Iran (4.2) and Afghanistan (3.7 per cent) (Udlændinge-og Integrationsministeriet 2018). Among those from Western countries, the number of immigrants was much higher than for their descendants. Their net immigration increased dramatically in the years 2007-2017, with the largest flow coming from Romania. Together, immigrants and their descendants constituted slightly more than 13 per cent of the residents of Denmark in 2018. This is a tremendous demographic change for a society which, until the late 1960s, was ethnically quite homogeneous. As late as 1980, the country had only 3 per cent of immigrants and their descendants among its population (Udlændinge-og Integrationsministeriet 2019). It is crucial to understand how this change was brought about and why many in Denmark do not wish this development to continue.

The beginning of its transition from a fairly homogenous Denmark to the contemporary multi-ethnic state it is now is explained partly by the Danish industry's need for labour in the 1960s and partly by refugee flows in subsequent decades. In 1967, the first foreign workers - known as guestworkers - arrived from Turkey, Pakistan and (the former) Yugoslavia. The catalyst and main external cause of the guestworkers' arrival in Denmark was the temporary economic downturn in Germany after a long period of growth and increasing needs (Hjarnø 1983). This temporary downturn meant that Turkish guestworkers, in particular, spontaneously ventured north. The internal factor which legitimised the import of foreign labour to Denmark was the boom in the Danish economy, which lasted until 1973 and which brought infra structural changes, a rapidly growing universal welfare state, the expansion and proliferation of long term education and shifts in the attitude of the new generation to the labour market (Albæk et al. 1992). It was widely believed that the increased demand for labour in certain parts of the industry could not be met by the domestic workforce alone (Würtz Sørensen 1988b). The lack of domestic labour was significant, especially in the manufacturing industry and in unskilled and low-paid work. If the industry's need for labour was not covered in the short and long term, labour shortages were likely to give employees incentives to demand wage increases, leading to supplyand-demand-driven inflation, with a subsequent deterioration in competitiveness (Albæk et al. 1992).

Six years later, in November 1973, due to the rise in unemployment, the government, trade unions and employers' organisations agreed to immediately stop the immigration of guestworkers. However, the flow of refugees (from Vietnam, Chile and, later, Iran, Afghanistan, Lebanon, Somalia, Iraq, Syria etc.), together with the internationally guaranteed right to family reunion, contributed to the growing number of refugees and migrants in Denmark.

The first Migration Act in Denmark was introduced in 1983. It was described by some as the world's most liberal immigration law and one of its most humanitarian asylum policies. Critics who, back then, were labelled as radical right 
(almost racist) by dominant mainstream parties, pointed out that it was too easy to enter the country. In the following years, the immigration and asylum policy was tightened - the first time in 1992 - and reformed several times after 2002, when the liberal-conservative government, together with the Danish People's Party, tightened the rules on family reunification.

\section{The history of policy results, migration management and integration policy}

With regard to demographic and socio-economic composition, there are certain interesting differences when comparing native Danes, on the one hand, and the population of immigrants and descendants, particularly non-Western immigrants and their descendants on the other. The latter have an age distribution that differs significantly from the rest of the population. There is a much larger proportion of children and young people. Only 7 per cent of the non-Western immigrants are more than 65 years old compared to 21 per cent of the native Danes. Among their descendants, there is an even bigger proportion of children and young people -80 per cent of them are under the age of 25 . This implies an overwhelming share of children and young people among the non-Western immigrants and their descendants (Udlændinge-og Integrationsministeriet 2018). The group of immigrants - of both Western and non-Western origin - is mainly composed of persons of working age, i.e. 16 to 64 years -82.9 per cent of immigrants of Western origin and 85.3 per cent of non-Western origin are aged $16-64$.

\section{Participation in the education system}

A look at the most recent data on immigrants' and their descendants' participation in the Danish education system reveals that 79 per cent of 16- to 19-year-olds of non-Western origin are in education. For the same age group of Danish origin the figure is slightly below 83 per cent. Of the female 16- to 19-year-old descendants of non-Western origin, 69.5 per cent are studying at college or are in vocational or higher education - a figure which is slightly higher than the corresponding proportion for women of Danish origin (65.4 per cent). This means that, in the near future, the Danish labour market will receive many applications for skilled positions from non-Western migrants and their descendants (Tal og Fakta 2019).

\section{Labour-market attachment}

There are currently 3.6 million persons in Denmark in the occupationally active age range - i.e. individuals between the ages of 16 and 64 years. On average, 7 out of 10 people (72.8 per cent) are employed. This corresponds to about 2.6 million 
people. The employment rate among male and female non-Western immigrants aged 25 to 64 years is 58 per cent and, for corresponding female non-Western immigrants, only 47 per cent in 2016. The difference between the employment rate for 25-64-year-old native women and immigrant women of non-Western origin was 30 per cent in 2016, which was perceived as disastrous. The most significant differences in the employment rate are found among women aged 50-59, where the difference between native women and immigrant women of non-Western origin is 39 per cent. The corresponding difference between native men and immigrant men of non-Western origin in the same age range is 34 per cent. The smallest gap in the employment rate between persons of Danish and those of non-Western origin, respectively, is observed among men aged 16-24 which, all other things being equal, should be considered good news for future development.

\section{Welfare}

Non-Western immigrants and their descendants are over-represented among the recipients of unemployment 'cash aid' (those with insufficient employment records to get unemployment benefits) - 19 per cent are non-Western immigrants. Male and female immigrants from Syria, Somalia, Lebanon and Iraq have the highest rates of persons receiving cash aid - for the women in this category, seven out of ten are on public support in general.

\section{Self-employment}

Immigrants - and especially non-Western males - are significantly over-represented among the self-employed. Non-Western immigrants are also over-represented at the bottom of the job hierarchy ('other employees') and under-represented at the top of the job hierarchy ('senior executives and employees at the highest level' and 'middle-level wage earners'). For Western immigrants, the picture is slightly different. They are also over-represented at the bottom of the job hierarchy but, unlike non-Western immigrants, have almost the same percentage of positions at the top of the job hierarchy as the Danes.

\section{Citizenship}

With regards to citizenship, the data (Udlændinge-Og integrationsministeriet 2019) reveal that around 35 per cent of immigrants and their descendants have Danish citizenship, with the descendants of migrants of non-Western origin demonstrating the highest rate (73.4 per cent). Immigrants of Western origin do not seem eager to apply for Danish citizenship, as only 13 per cent have it. 


\section{Shahamak Rezaei and Marco Goli}

\section{Expenditure}

According to a recent estimation, non-Western immigrants and their descendants cost Danish society 4 billion euros in 2016. The calculations include some 719,000 people's imprints on government finances, in terms of what this group contributes to the community in the form of tax revenue and what they cost the state in spending on, for example, transfer income, education, the judicial system and health care (Funding 2019). Criticising the calculation, a member of the Danish Social-Liberal Party stated:

We are a bit critical of the calculation because a lot of immigrants and their descendants are children and young people. Children and young people are, by definition, a cost but, if they do well in the education system, they will later become a benefit.

(Waarsøe and Funding 2019: 1, Authors' translation)

\section{Public opinion, the position of trade unions and political developments}

Since the very beginning - the late 1960s and early 1970s - both the integration and migration problems, challenges or, as they recently have been framed, threats, implicitly (and over recent years increasingly outspoken) refer, quite often exclusively, to the category of immigrants and descendants from non-Western countries. Similarly, public opinion and mainstream discourses depart from and continuously highlight that this category and, to be more accurate, a particular substratum of this category - i.e. immigrants and descendants from Muslim countries - not only face the greatest integration challenges in terms of unemployment but also oppose Danish discourses of integration, which have shifted from integration in the labour market as the criterion for success, to cultural integration or assimilation and societal cohesion. They are portrayed as those who set up 'parallel societies', in competition with and even hostile to the norms of mainstream Western, Nordic society.

Initially, back in the 1960s, it was widely believed that there was no planned largescale import of labour. The widespread perception at the time was that the guestworkers had appeared more or less spontaneously on the Danish business landscape and that they would disappear again as soon as the industry no longer needed them (Würtz Sørensen 1988d). However, they stayed and they grew in number. In order to find out how and why, we have to look at the attitudes of the stakeholders involved.

For the trade unions, the guestworkers were uninvited/unwelcomed. However, from the perspective of employers and the government, they were considered to be highly welcome guests (Hjarnø 1983; Würtz Sørensen 1988c). As far as the general population's attitudes towards foreign workers were concerned, opinion polls back then showed clearly that, regardless of the economic situation, the Danish population had not at any time been predominantly positive in relation to the import of foreign labour. Their concerns in many ways resembled attitudes today (Würtz Sørensen 1988a; Togeby 1996, 1997) (Figure 7.1). 


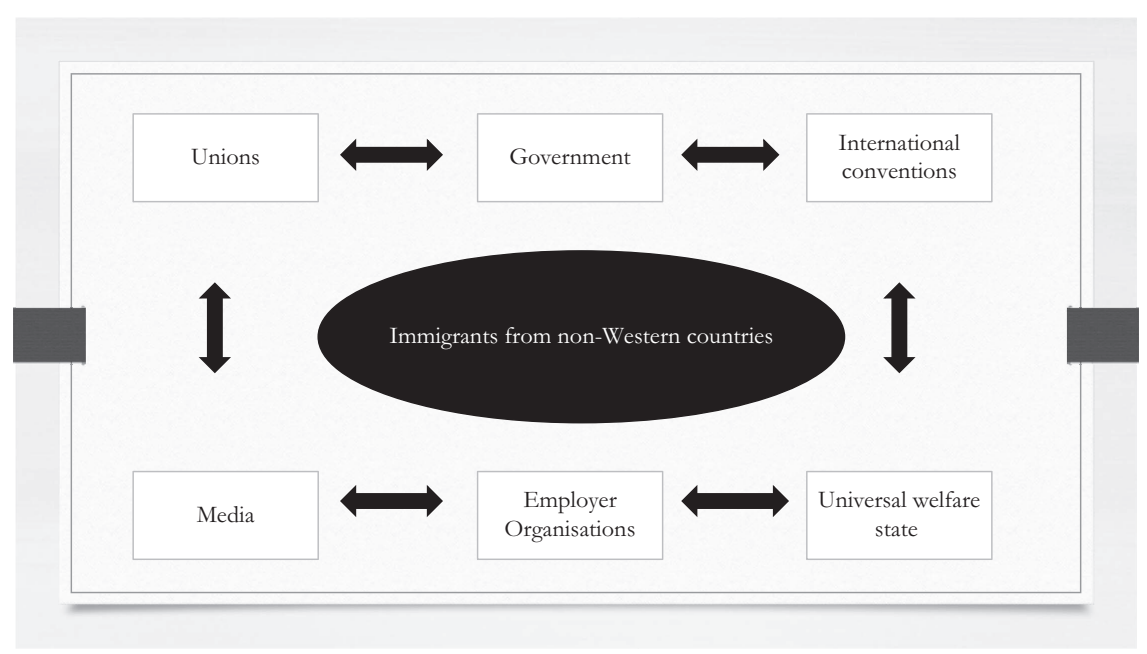

Figure 7.1 The positioning of the import of labour from abroad in the early 1970s Source: developed on the basis of Goli (2002)

There was a variety of arguments for and against the import of foreign labour. Employer organisations' arguments for importing labour were:

- a better utilisation of the capital stock of labour-intensive companies,

- an increase in production,

- a reduction in wage levels with consequent greater competitiveness, and

- foreign workers would not compete with Danish workers, as foreigners would have to go home or be fired as soon as the demand for their labour ceased.

Speculation on the consequences of the liberal migration regime and, later, the humanitarian asylum policies for social and cultural cohesion in Denmark is not a new phenomenon. There had already been concern in the early 1970s that the immigration of foreign labour would have an impact on future society, not least in terms of demographic challenges. For example, Kaj Westergaard wrote: 'Denmark is an extremely homogeneous country without ethnic or religious minority groups of importance' (cited in Hjarnø 1983: 13). Some of the problems that had already arisen in the early stages were explained by reference to culture, where the Danes met 'new neighbors with miserable housing conditions and with quite deviant and far more demanding - lives, including in particular poor wages and bad labour conditions in general' (Hjarnø 1983: 15). So which externalities are linked to the use of foreign labour? Westergaard presented (Hjarnø 1983: 16) a cost-benefit analysis. The costs included increased investment in jobs in the public sector, housing costs, education and social rights, and the export of income and savings. The benefits mentioned were the excess capital of the capital stock, the reduction of inflationary pressure on wages and prices, direct and indirect taxes, the elimination of 
acute bottlenecks in production (immigrants were single, young and mobile males) and the fact that foreign workers increased the proportion of the active population and filled gaps in production. The latter could, according to Westergaard (Hjarnø 1983) generate a domino reaction - i.e. the cultivation of Danish labour. However, the interests of the employers, the foreign labour and the government converged, while the interests of the Danish trade unions were the complete opposite.

\section{The dilemma of the trade unions}

Already in 1967, the National Umbrella Union's Chairman stated that it was necessary to ensure that foreign labour did not erode domestic workers' wage-bargaining position. The trade union's attitude at the beginning of this period was characterised by a dilemma between three concerns, respectively for domestic workers (native Danes) and their members; for solidarity with foreign comrades; and for national economic growth and competitiveness. These concerns were mutually incompatible. The dilemma was reinforced by the fact that the import of unskilled foreign labour particularly out-competed the unskilled among the domestic labour forces - i.e. the weakest among Danish workers. Next, the trade unions had both implicit and explicit co-responsibility for the improvement of Danish industry's competitiveness, as industry, the government and the employer organisation argued on numerous occasions. Traces the history of the trade union's dilemma back to 1905 and 1907 - to two international congresses held in Amsterdam and Stuttgart respectively. Here, social-democratic parties were confronted with proposals to oppose any kind of importation of contract workers, among other things, by demanding control over labour imports, wages and working hours, demands for payment for travel, acceptable housing conditions, the training of immigrant workers and, finally, ensuring that foreign workers were not recruited if domestic labour were available (Hjarnø 1983). The so-called Polakker-Lov (Polish Act on the Use of Foreign Workers of 1908) was an expression of this endeavour: prior to this law, claims were made especially from the Social Democracy, but also by the Catholic Church and by employers. The employers' interest in protecting the Polish immigrants was to avoid that Denmark gets a bad reputation causing difficulties in recruiting necessary people (Nelleman 1973).

The trade unions, therefore, had to learn to master the art of balancing and reconciling the interests of domestic workers, the concern for the national competitiveness and the long-praised tradition of solidarity with the international working class. Opposing 'the massive deprivation among, and exploitation of foreign/ guest workers', reported repeatedly in the press (Würtz Sørensen 1988a) came to be the key word and strategy in the trade unions' efforts to curb the influx of foreign labour - in the report 'Same Terms' (Andersen 1970) these arguments were formally formulated.

\section{Same terms (Samme Vilkår)}

The trade unions had already managed to make provisions that foreign workers should be registered, that they should be contributing members of a sickness 
and unemployment fund and that employers should be obliged to pay wages in accordance with the level agreed upon through collective agreements. Würtz Sørensen argues (1988d) that, in the middle of the 1970s, the trade unions were in favour of a temporary halt, and they managed to convince the public through massive campaigns and activism. Gallup and Observa, two leading quantitative research institutes, showed in surveys studies in 1969 and 1970 that a majority of the population opposed the continued import of foreign workers and 80 per cent believed that foreign workers should be subjected to the 'Same Terms' (Andersen $1970)$ - i.e. to equal treatment.

The trade union's slogan 'Same Terms' was then supported by concrete proposals for solving problems regarding the foreign workers' wage, housing, employment, occupational and leisure conditions and contracts with their employers. By the end of 1973 and as a consequence of the international oil crisis and the following recession, the great majority of guestworkers were fired, in accordance with the theoretical propositions of the 'dual market theory' (Rezaei 2004), which indicated that the last to be hired would be the first fired; they were equal in almost every way with domestic workers but had lost their competitiveness, which mainly was limited to their being cheaper for the employers (they did not require the same wage) and to their being satisfied with working conditions which were much below the standard. Their competitive advantage was eroded systematically through 'Same Terms'. In the following years they changed their status from guest- and foreign workers and immigrants to 'ethnic minorities' and the construction of ethnicity, cultural differences and multiculturalism began to develop.

\section{The construction of ethnicity in Denmark}

Designations such as 'foreigner', 'foreign/guestworker' or 'immigrant' were common concepts in political and public debate and common denominations in parliamentary debates right up to the 1990s. Academic research on the issues of both migration and integration in Denmark which, according to Schierup (1993) has, due to its emancipatory and critical approach, always been involved as a stakeholder and not just a neutral observer or provider of objectively reliable data, was already, from the beginning, somewhat occupied with the construction of 'ethnicity' and the term 'ethnic minorities'.

Over the following years, particularly in the 1990s, the concept of ethnicity and ethnic categorisation became popularised in Denmark, with a stigmatising and social labelling bias. In public and political debate as well as in academic research the concept of ethnicity, most usually with a negative connotation, refers exclusively to migrants and descendants of non-Western origins. It is, in Denmark as well as in other Scandinavian countries, appropriate to address and approach individuals with, inter alia, a Turkish, Pakistani or Somali background, as members of ethnic minorities but it would be inappropriate, even surprising, to address and approach in the same manner a person, for instance, from EU countries such as Poland, Spain, France etc. - in other words, practically anyone who is a whiteblonde 'ethnic'. The latter have national backgrounds while the first group are 


\section{6}

supposed to have ethnic backgrounds. 'Ethnic' in the Danish context means deviant and a challenge, whereas 'non-ethnic' implies 'similar to us', therefore not a cultural challenge.

\section{EU enlargement}

\section{Migrant inflow}

The number of 'non-ethnics' has grown rapidly in recent years. In 2011, 52,979 individuals received a residence permit on various grounds in Denmark - the lowest number over the last ten years. The number of residence permits issued peaked in 2015 at 84,693 . It is noteworthy that the group of refugees who have been granted asylum in Denmark, despite the much greater political and public attention, represents a quite tiny proportion of the total immigration to the country. Refugees and family reunion together make up less than 3.5 per cent of all types of immigrant who went to Denmark in 2018. In comparison, just over half of the people who received a residence permit in Denmark in the same year were holders of an EU-country passport.

In 2018, 139,854 individuals from EU countries other than the Nordic ones resided in Denmark (Videbæk and Gyldenkærne 2019). Earlier, the number was 99,809 people, which corresponds to an increase of about 40 per cent in four years. Looking at the development of net immigration by origin from 2007 to 2017, national statistical data reveal that the net immigration of people of Western origin has been increasing dramatically; the total net immigration in 2017 was 25,000 individuals, divided into almost 12,000 non-Westerns, 11,300 Westerns and around 1,500 Danes. The net immigration from non-Western countries fell from just under 25,300 in 2015 to just under 12,000 in 2017, mainly due to the decline in the number of refugees and family-reunion migrants going to Denmark. The largest immigration country in 2017 was Romania, with a total net immigration of just over 2,000.

\section{An identical game, played differently}

A quite similar, in fact almost identical, scenario, although with a few still dominant differences, has been observed since the eastward enlargement of the EU (Figure 7.2).

In public opinion, migrants from EU countries are not very different to native Danes with regard to cultural norms. Their social identity is not portrayed as deviant in any way. Quite the contrary, they have a positive image in public opinion. Denmark being a member of the EU, no official or semi-official persons (from unions, NGOs etc.) or political parties in the country are allowed to mount moralpanic campaigns against migrants from Poland or Romania. Due to their supposed considerable similarities with regard to cultural preferences, migrants from EU countries are expected to adopt to Danish norms quite quickly, too. 


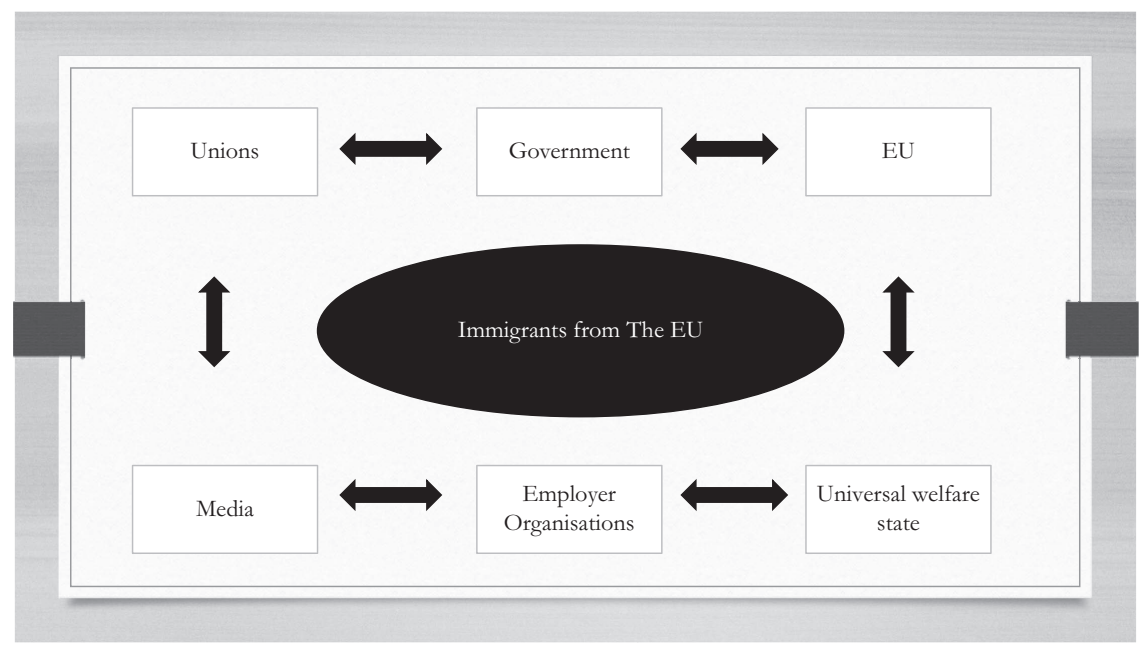

Figure 7.2 The positioning of the import of labour from abroad in 2019 - An identical game, played differently

Source: developed on the basis of Goli (2002)

Monika, from Poland, is a good example. She went to Denmark from Poland for the first time following the eastward enlargement of the EU in 2004. Back then, Monika picked berries and cut trees in a small town in the Zealand region of Denmark. Illustrating why labour from Eastern European EU member countries seek to migrate west (to Denmark), Monika stated, in appreciation of the Danish labour market culture, 'Here in Denmark I can talk and drink coffee with my boss. In Poland you just have to work, work and work, and there is a big difference between employees and bosses' (Videnbæk and Gyldenkærne 2019).

Unlike many migrants from non-Western countries who migrate to Denmark under the family reunion act and all refugees who, by definition, do not go to Denmark with the particular aim of seeking a job, EU migrants' primary motivation for travelling to Denmark is to work. Many of them do not even wish to stay in Denmark if they do not find a job - which is in itself unusual, as they typically have a contract with an employer in their own home country or with an employer in Denmark, prior to arrival. The free movement of EU citizens, an established framework in which every issue related to the residence and work and rights of EU members should be addressed, indicates that, as an EU citizen, an individual has the right to seek work in another EU country and to work without a permit: to stay there while they work, to stay there even when their employment contract ends and to be treated equally with the country's own citizens with regard to access to work, working conditions and all other social rights and tax benefits. 
For the first five years, Monika travelled back to Poland when there was no work; however, she then landed a permanent job with a local firm. She decided to stay:

I am happy to work with Danes, and I would like to stay here, because I love this country. . . . It is important to us that it is stable here. And that one does not need to worry. . . . Another advantage is the culture of the labour market. EU migrants are easy to integrate linguistically, as well as with regard to culture and norms.

The same attitude is expressed by 'Dansk Byggeri', a Danish organisation which represents companies in the building and construction sector (Videbæk and Gyldenkærne 2019).

There is also widespread recognition of EU migrants' contribution to the Danish economy, as stated by Steen Nielsen, head of labour market policy for Danish Industry in 2018:

In fact, a very large part of the job progress and growth we have had in Denmark in recent years is because we have received more foreign employees.

'It does not take long, on arrival in Denmark, for a person from Poland to integrate into Danish norms and contribute to the Danish labor market', says director Lars Storr-Hansen (Videbæk and Gyldenkærne 2019). Both Danish construction and Danish industry express satisfaction with and welcome (EU) workers who wish to stay permanently. The reason?

This means that Danish companies can grow big and strong. . . . Many companies are very dependent on their foreign employees and they would have difficulty coping with challenges and increasing demand without those worker.

(Videbæk and Gyldenkærne 2019)

As mentioned before, issues concerning EU citizens are addressed within wellestablished EU law and represent mutual benefits - a principal of reciprocity, as the same goes for Danes who might wish to settle or work in other EU countries. However, this is not the only difference. What is probably even more important, at least with regard to public discourse on migrants and integration, is the question of their cultural integration. EU migrants do not represent any significant 'otherness', cultural deviance, cultural challenges or clashes of art. They do not demand the protection of their collective cultural rights, as has been reported in many cases with regard to 'non-Western migrants and their descendants', a category which, when addressing cultural differences, exclusively refers to migrants and their descendant with a Muslim background. Another aspect that should be mentioned is that EU migrants and their descendants do not deviate from everyday norms of behaviour. It is probably unpleasant to mention, although still very crucial, that migrants from EU countries, unlike non-Western migrants and their descendants, are not 
visible minorities. By the same reasoning, EU migrants do not experience or invoke tribal stigmatisation, which can be a devastating experience for many non-Western migrants and their descendants, who might feeling that their belonging to the national community, despite having been born in the host country, is implicitly and occasionally explicitly questioned based purely on their physical appearance. They represent 'the stranger' (Wolff 1950). The status of a stranger shapes the everyday life experiences of belonging to the national community and the demarcation of 'us' and 'the others'. When approaching a person who does not look 'Danish' - for instance, someone whose phenotype is African or Middle Eastern - there are still Danes who speak English to them or ask them if they speak Danish. They cannot know that the person was born in the country. When approaching a person from Poland, Romania or Ukraine, they start speaking Danish to them, sometimes only to find out that they have only been in the country a single day (Goli 2002).

\section{The migration paradigm shift and the elections of 2019}

By 1 March 2019, three months prior to the national elections, a new act was put in operation - 'The Paradigm Shift in Danish Integration Policy' (Ingvorsen 2019) which contains major institutional and discursive revisions of the Aliens Act, the Integration Act and municipal and regional electoral law. The new act covers policies within the field of integration as well as migration management, particularly the elements of migration that concern refugees and migrants from non-Western countries. The act is, in many ways, the culmination of an ongoing showdown with the dominant premise from which Danish migration and integration policies have departed over the years. Included in the new act are three provisions:

1 Residence permits for refugees, in future, will only be temporary. The residence permit for refugees and family reunion will be withdrawn or exempted where possible, unless it is in direct conflict with Denmark's international obligations. Refugees must be returned to their home countries whenever possible. In the future, it will also be possible to set a limit on the number of family reunions. In such cases, the limit can be set from month to month.

2 The name of the 'integration benefit' that refugees have received has changed to that of 'self-support' or 'repatriation' - i.e. deportation. If an individual has legally resided in the kingdom (Denmark, the Faroe Islands or Greenland) for a total of at least nine years within the previous ten years and met the employment requirement, he or she can get cash or educational assistance if needed. Integration benefit is a substitute for those who do not meet the requirement to be entitled to 'cash assistance' - i.e. persons who have stayed in the kingdom for a short time can get integration benefit. The term 'return assistance' or repatriation aid is chosen to emphasise that residence permits are temporary. With the term 'self-support', the act seeks to ensure that refugees take responsibility for their own integration. At the same time, the benefit is reduced by 250 euros a month (which is a considerable amount/share of money for individuals at the absolute lowest end of the income hierarchy). 
3 The legal residence period required before a foreigner may vote or be elected to local government has been extended from three to four years.

The so-called Paradigm Shift was an absolute requirement of the Danish People's Party prior to negotiations on the budget act with the government. Explaining why the act is called a 'paradigm shift', PM Peter Skaarup, one of the most prominent members of the Danish People's Party, stated: 'This means that we turn the whole policy in this area upside down from today, from being about integration, to being about repatriation'. The Paradigm Shift was supported by the Social Democrats, the party that came to power after the June 2019 election. During the election campaign, the leader of the Social Democrats stated repeatedly that she would give up the wish to become the prime minister of Denmark if she was unable to tighten the migration and integration policies. Emphasising and celebrating the contribution of the Danish People's Party to the tremendous tightening of the migration and integrations policies prior to the June election, Martin Henriksen, a prominent member of the party, listed 144 austerity measures in the policies. These include:

- border control,

- the limitation of freedom of belief for the purpose of affecting political Islam,

- the prohibition of wearing the burka in public spaces,

- an emergency brake that would allow asylum-seekers to be rejected at the border,

- the criminalisation of homeless/Roma camps,

- the encouragement of voluntary return/repatriation,

- annual calculations of immigration costs,

- the restriction of the number of English-language students at business academies,

- $\quad$ the introduction of the need to demonstrate at least 225 hours of paid work as a requirement for receiving cash aid,

- the introduction of a limit on total cash aid from governmental offices and agencies,

- the abolition of access for refugees to include residence time in the country of origin when calculating national pensions,

- $\quad$ a stronger monitoring and supervision of Muslim free schools; and

- $\quad$ the abolition of the Green Card scheme etc. (Henriksen 2019).

After the power takeover, no considerable reforms of migration and integration policies have been introduced by the Social Democrats. However, there is no doubt that discourses that were considered 'radical right' are today established as mainstream.

\section{Further steps to the right}

While the DP has become a mainstream party involved in policy-making within all areas, two new parties - the New Right and Hard Line - focus almost exclusively on migration and integration. The public and the media perceive them as being 
at the very far right end of the political scale as they do not find policy reforms like the Paradigm Shift and 144 austerity measures either substantial or efficient enough to safeguard the future cohesion of society. During the June 2019 elections, the New Right introduced a set of 'non-negotiables' under the heading 'A fair migration policy'. The main principles of this policy include the requirements that asylum be stopped completely, that foreigners must support themselves, that integration must be a personal responsibility and not a public task, that criminal aliens should be deported after the first sentence, that becoming a Danish national should require assimilation and, finally, that international conventions that stand in the way should be terminated.

The other party, Hard Line - even more radical - take it further to the right (Stram Kurs 2019). Their agenda is an uncompromised and complete showdown with migration and integration from (explicitly emphasised) Muslim countries. The party considers 'Muslim migrants and their descendants' as a 'non-integratable' population and has portrayed them actively throughout their campaign as not only culturally incompatible and deviant but hostile to Western/Danish culture. They actively question Muslim migrants' substantial loyalty to the nation-state and Western and Danish traditions, lifestyle, values, priorities etc. and see them as a growing demographic threat to the very existence of the nation. Muslim migrants are portrayed by Hard Line as invaders, a ticking time bomb. Throughout the recent elections, the party pushed for a complete showdown through some very confrontational street-level campaigns ${ }^{12}$ that repeatedly put them on the front pages of all the media.

Hard Line's party policies are categorised under two pillars - the Identity Pillar and the Libertarian Pillar. 'Identity politics' focuses, according to the party, on Danes as an ethnic, cultural, religious, linguistic and normative community. Policies departing from this pillar relate to actions that will maintain and improve national homogeneity. The key terms are 'community affiliation' and 'ethno-nationalistic cohesion'. The vast majority of residents in Denmark, again according to the party, must be Danes who ethnically, linguistically, religiously, culturally and normatively profess the same or related values:

- Hard Line does not recognise that Denmark must process applications for asylum from any person who is not a native citizen from one of Denmark's neighbouring countries.

- Denmark must withdraw from international conventions governing refugees.

- Denmark must expel any non-Western person who is not a Danish citizen. No 'non-Western' persons' temporary residence permit should be renewed.

- foreigners who have been granted Danish citizenship by law must have the citizenship reviewed and, as a rule, cancelled (Stram Kurs 2019).

\section{Conclusions: how did we get this far and what can we expect?}

A wide range of circumstances and factors will potentially contribute to the fundamental shift or the showdown in Danish migration and integration policies in 


\section{2}

years to come. First of all, the entire cognitive framework in and premises by which migration and integration causes and effects are evaluated, addressed and framed, not only by far-right parties but also by the mainstream parties - including the party that took over government power, the Social Democrats - have changed radically. Besides, considerable segments of native voters who somehow have the subjective feeling of being ignored by mainstream parties, have found their voices. The median voter has moved towards the right of the political scale.

With regard to the national identity and identification question - 'What actually makes up a Dane?' - we have just taken the very first steps towards an even more fundamental shift from inclusive nation-building, where integration and multiculturalism were considered as both the goal and the means, to an exclusive nationbuilding project in which only two options seem to be available: assimilation or segregation/deportation. The latter means a change from individually subjective choice- and will-based incorporation in the national community towards a collective objective ethnicity-based definition of nationhood.

The ethnic and ethno-cultural diversity which, during the 1990s, was the cornerstone of recognition, inclusive citizenship and 'multiculturalism' is now almost completely absent in public and political debate and discourse. It is replaced by the quite widely politically supported requirement of assimilation. Among economic causes that will push migrants from non-Western countries, specifically Muslims, to the margins, the role of the free movement of labour within the enlarged EU cannot be overestimated. EU enlargement has provided the Danish economy with the necessary and much more skilled labour from other EU countries. The free movement of new labour from the East is by nature regulated by the size of supply and demand curves - i.e. following economic rather than political or humanitarian rationales. The labour force from the 'new' EU countries seems to be much more attractive than those which Denmark used to get from non-Western countries, alongside a wide range of criteria, among which should not be ignored the importance of quite compatible cultural elements, including religion and religious affiliation, fundamental norms of behaviour and principles such as gender equality, democratic affiliation etc. Besides, the majority of new immigrants from the EU are not visible minorities, making 'the (might be) stranger' unrecognisable in the passage of everyday life (Goffman 1963).

A considerable share of the Danish population seem to feel that the universal welfare state has been burdened by non-Western immigrants and their descendants, that the national identity has been challenged and that values completely different from and, sometimes, opposite to their own have been introduced and have challenged social cohesion.

Even though the June 2019 national elections brought 'the reds' - the Social Democrats - into power and saw the end of 'the blues' or liberal-conservative government, it would be a mistake to consider this as a step to the left. The issue is, rather, whether the far-right parties themselves would carry these new priorities into Danish institutions or whether these policies would be adopted even more obviously and systematically by mainstream parties in power. Today's Social Democratic Party (the new government) is, with regard to its policies towards 
migration and integration, completely different to what it was two to three decades or even five years ago. They have adopted a wide range of 'Danish People Party' standpoints, rhetoric and policies.

No matter whether red or blue, the governments of today and of tomorrow should be expected to act in accordance with and to further institutionalise dominant previously named radical-right discourses by demonstrating substantial shifts:

1 from a reactive to a pro-active policy: it is in charge; it is able to control the flow of migration from non-Western countries;

2 from humanism to utilitarianism: it can reallocate the resources from helping non-Western migrants residing in Denmark to refugees in their own or neighbouring countries and regions;

3 from universality to particularity: it can bind the social rights of individuals to social duties towards the community and the state;

4 from globalism to nationalism: it can demonstrate greater concern for the nation's own children, youth and the elderly - i.e. the natives - than for the equivalent citizens of other countries; and, finally;

5 from principled politics to realistic/pragmatic politics: it can sacrifice party principles whenever needed and argue in favour of the most practical solutions.

These circumstances are here to stay, making further moves towards the right end of the political scale unavoidable. Nevertheless, it is obviously not a move towards 'the right' as we defined it traditionally. In order to comprehend what is happening, we should probably invent a new concept that would encompass the core features of the new phenomenon. We would call it the 'Rational Right'. The concept, to be further investigated, refers to a political joint venture between parties and movements which mutually disassociate themselves from each other's conflicting ideologies but which, despite this, bring parties and movements together under a new umbrella, where discourses of neoliberalism, competition state, efficiency, concern for social cohesion and national interest, pragmatic policy and practicality and, finally, reciprocity with regard to the nation-state's obligations towards nationals of other countries, are the core pillars.

\section{Notes}

1 See https://nyeborgerlige.dk/politik/udlaendingepolitik/

2 See https://stramkurs.dk/Stram Kurs

\section{References}

Albæk, K. et al. (1992) Kampen mod Ledigheden. Copenhagen: Spektrum.

Andersen, C.D. (1970) Samme Vilkår: DASF Udvalgsrapport om: Fremmedarbejderproblemet Udarbejdet af Carl Damsted Andersen, John Mølgaard og Kaj Buch. Copenhagen: Dansk Arbejdsmands-og Specialarbejder Forbund. 


\section{4}

Bøgelund Nielsen, E. (1984) Indvandrerpolitik i Danmark. Roskilde: Roskilde University Denmark, unpublished $\mathrm{PhD}$ thesis.

Funding, T. (2019) Nye Tal: Indvandringen Bliver billigere, Men Koster Stadig 30 Milliarder Kroner Arligt. Available at www.fyens.dk/danmark/Nye-tal-Indvandringen-bliverbilligere-men-koster-stadig-30-milliarder-kroner-aarligt/artikel/3342311 (accessed 30 October 2019).

Goffman, E. (1963) Stigma: Notes on the Management of Spoiled Identity. Englewood Cliffs, NJ: Prentice-Hall.

Goli, M. (2002) En verden til forskel. Copenhagen: Institute of Political Science, University of Copenhagen, 2002.

Henriksen, M. (2019) Dit Overblik. Available at https://ditoverblik.dk/df-goer-listen-op144-stramninger-i-udlaendingepolitikken-siden-2015/ (accessed 29 September 2019).

Hjarnø, J. (ed.) (1983) Indvandrerforskning i Danmark. Copenhagen: Akademisk Forlag.

Ingvorsen, E. (2019) Paradigmeskiftet'vedtaget $i$ Folketinget: Her er stramningerne på udlcendingeområdet. Dr-Nyheder. Available at www.dr.dk/nyheder/politik/paradigmeskiftetvedtaget-i-folketinget-her-er-stramningerne-paa-udlaendingeomraadet

Nelleman, G. (1973) 'Polske vandrerarbejder i Danmark 1893-1929', in Landbohistorisk Tidsskrift (2002:1). Denmark: Auning Dansk Landbrugsmuseum.

Rezaei, S. (2004) 'Det duale arbejdsmarked i et velfærdsstasligt perspektiv - et studie af dilemmaet mellem uformel økonomisk praksis og indvandreres socioøkonomiske integration', Delrapport 2, University of Roskilde.

Schierup, C.U. (1993) På Kulturens Slagmark. Copenhagen: SDU Denmark.

Tal and Fakta (2019) Tal og fakta på udlcendingeområdet. Udlændingestyrelsen.

Togeby, L. (1996) 'Danskerne og de fremmede', in Social Forskning. København: SFI.

Togeby, L. (1997) 'Er vi ved at vænne “os” til “dem”?', Politica, 29. årgang, Denmark.

Torfing, J. (2003) Den stille revolution $i$ velfcerdsstaten - fra forsørgelse og hierarki til aktivering og netvarksstyring. in "Drivkræfter bag arbejdsmarkedspolitikken", Per Kongshøj Madsen og Lisbeth Pedersen (red.). Socialforskningsinstitutttet.

Udlændinge-og Integrationsministeriet (2018) Integrationsbarometer. Denmark.

Udlændinge-og Integrationsministeriet (2019) Tal og Fakta. Denmark.

Videbæk, K. and Gyldenkærne, P.G. (2019) 'Flere gør som polske Monika og slår sig ned i Danmark: 'Jeg elsker det her land', DR-Nyheder. Available at www.dr.dk/nyheder/ politik/ep-valg/flere-goer-som-polske-monika-og-slaar-sig-ned-i-danmark-jeg-elskerdet-her (accessed 30 October 2019).

Waarsøe, L. and Funding, T. (2019) Tre Politiske Meninger om Fcerre Udgifter til Indvandring. Available at www.fyens.dk/danmark/Tre-politiske-meninger-om-faerre-udgiftertil-indvandring/artikel/3342312 (accessed 29 September 2019).

Wolff, K. (1950) The Sociology of Georg Simmel. New York: Free Press.

Würtz Sørensen, J. (1988a) Der Kom Fremmede. Migration, Højkonjunktur, Kultursammenstød. Fremmedarbejdere i Danmark frem til 1970. Åarhus: Åarhus Universitet, Center for Kulturforskning, Working Paper No. 1.

Würtz Sørensen, J. (1988b) Danskerne og de Andre. Åarhus: Åarhus Universitet, Center for Kulturforskning, Working Paper No. 5.

Würtz Sørensen, J. (1988c) Hvor Dansk? Så Dansk! Den Politiske Debat om Indvandrerintegration i 70'erne og 80'erne. Åarhus: Åarhus Universitet, Center for Kulturforskning, Working Paper No. 11.

Würtz Sørensen, J. (1988d) Velkommen Mustafa? Debatten om Goestearbejderne og det Danske Samfund i Starten af 1970'erne. Åarhus: Åarhus Universitet, Center for Kulturforskning, Working Paper No. 17. 